\title{
Technology Adoption of Complete Feed by Cattle Cow Breeder
}

\author{
Tanri Giling Rasyid, Amrullah T, Sofyan Nurdin Kasim, Ikrar Moh. Saleh, St. Rohani \\ Department of Social Economy of Animal Science Faculty, Hasanuddin University, Makassar, South Sulawesi, Indonesia
}

Received date: 10 January 2018, Accepted date: 28 March 2018, Online date: 4 April 2018

\author{
Address For Correspondence: \\ Tanri Giling Rasyid, Hasanuddin University, Social Economy Department, Animal Science Faculty, 90245. Makassar, Indonesia. \\ E-mail: tanri.giling@gmail.com
}

Copyright (C) 2018 by authors and American-Eurasian Network for Scientific Information.

This work is licensed under the Creative Commons Attribution International License (CC BY).

http://creativecommons.org/licenses/by/4.0/

\section{(c) (j) Open Access}

\begin{abstract}
Field issue showed that the average of cattle cow breeder cultivate their cattle by shepherded them it is because of their knowledge about fermented feed or complete feed still low. This low knowledge impact with the amount of cultivates cattle which are between 3 cows to 5 cows, and making raising cattle just as a side job. Then food crops agriculture as their main business. With this low knowledge about feed so that this research directed and aimed to review technology adoption complete feed by cattle cow breeder which is conducted with learning by doing training in September 2018. For the purpose of this research so the data and fact gathering from 25 cattle cow breeder that chosen with purposive sampling and it was held at Gowa Regency, South Sulawesi Province. The writer collected the data by giving questionnaire at the beginning and at the end of research, and then the first data and the last data being compared to each other to know the knowledge that they have. This approach in methodology is called pre-test and posttest. The result of the research shows that from 25 cattle cow breeder whose join the training there is a change in their knowledge which is, in the beginning, they still did not know fermented feed or complete feed and in the last training showed their knowledge is increasing or from not knowing to become knowledgeable also with this treatment made the cow breeder become interested because from cow favor toward fermented feed or complete if compared to shepherded, if reviewing from profit the daily weight of cow that reach with shepherded way only $0,15 \mathrm{~kg} / \mathrm{cow} / \mathrm{day}$, then by using complete feed can reach $0,35 \mathrm{~kg} / \mathrm{cow} / \mathrm{day}$. And positive correlated with financial profit which is for 4 months fattening with complete feed per cow cattle can give profit as much as IDR. 3.090.000,- than with using feed shepherded way can get IDR 1.440 .000 ,- with market price regulation for beef at that time of research is IDR. 80.000 ,- per kilogram. Technology adoption fermented feed or complete feed that given as learning by doing to the breeder gives the attitude change to the cow cattle breeder knowledge from using field from as shepherded to used fermented feed or complete feed because it gives more benefit for the daily weight gain and the duration of cow cattle fattening is really in just in a short time and also it give profit financially.
\end{abstract}

\section{KEY WORDS}

Breeder Profit, Cow Cattle, Fattening, Feed Technology.

\section{INTRODUCTION}

Self-support beef is a hope for every single country because society life that really needs food including beef that comes from cow cattle. In 2010 and 2014 Indonesia government hopes self- support beef, but with the way this program cannot reach as their hope. That Indonesia government plan a program to progress the selfsupport of beef (P2SDS) with the target in 2014 Indonesia able to produce beef 90\%-95\% from national necessity $[1,2,3,22,23,24]$

With the target unreachable Indonesia government so it gives task to [4] to collecting the data the cause of failure it is because cow breeder did not focus yet on cow breeding and only as a side job because of farmerbreeder focused on managing the land, maintenance the plant, the time that given to the cow is very little, and considering the cow cattle need a long time to cultivate and consider that forage is seasoning readiness.[5] the result of their research shows that livestock citizen system really high dependable on the shepherded system, this is caused by: a) low knowledge from breeder about the importance of quality of forage that impact with cattle 
cow productivity, b) breeder have limited information access, c) Reeder did not have land to plant top quality forage because most of the land cultivate to crops plant, d) local climate condition that less profitable for example the low rainfall, to long dry season, less fertile land, and e) less of breeder knowledge about forage cultivation

[6] given an example if mastered feed technology so almost every cow breeding routine can be done for example nutrition value of meat can be increased with utilization of microbes which known with the term soled state fermentation, in this case carbohydrate content can be fermented easily with some of the microbes because these microbes need carbohydrate, nitrogen un-organic and some of the mineral such as iron, zinc, calcium, for their growth.

The consequence of feed technology knowledge that has not have yet for most of the cow breeder so that the breeder did not want to cultivate their cow cattle with amount more than 5. That weak of technology knowledge by breeder so that on the dry season the breeder confused to find the feed and on the rainy season forage has rich amount but cannot be managed to become feed, at the time the available of forage has reach the lowest season, plus the breeder always thought that feed beside the field forage is expensive, it causes the cow breeder to become the side job $[7,8]$. $[9,10]$ said that the best solution so that the breeder can diligently to using their cow cattle to the best so that it need knowledge to the breeder with the training intervention as learning by doing in the terms of cattle forage management to become fermented feed. [11] stated that superiority complete feed and fermented is to balance the nutrition of the cheap feed ingredients. And this case it is possible because the main ingredients of the feed come from agricultural waste and agro-industry as their supplement ingredients with high nutritional value. Given example [12] and [13] the using of radish tubers, skin of passion fruit flour, and others agricultural waste can be combined with others ingredients to make complete feed/fermented that can produce the increase of daily body weight as for cow cattle $0,3-0,5 \mathrm{~kg} / \mathrm{cow} /$ day and goat $80-105$ gram/goat/day. Also [14] and [15] advised ruminants feed should come from cheap ingredient, for example, industrial waste such as rejected radish add with leaf and other ingredients because have biomass potential for about $20 \%$ or contain with high enough soluble carbohydrate (BETN) for about 37,20\%.

From a low level of knowledge of breeder in terms of utilization agricultural waste and agro-industry waste that have cheap value to make complete feed or fermented, this case can be a solution for the breeder to become interested in focusing cow breeder so that the supply chain can be fulfilled continuously.[16] advised from her research result that giving a training and accompaniment to make the quality of feed and cheap prices like ureamolasses block because can be a positive impact for the cattle cow which is increasing production and the cow body weight gain with average $0,3-0,5 \mathrm{~kg} / \mathrm{cow} /$ day. [17] said increasing population program and cow cattle productivity should referring to some of the research result above and if associated with field identify result so that this research want to give a solution with focus of research directed to breeder knowledge about fermented feed or complete and compare with the feed that it giving now, also from daily body weight gain aspect and time period to fattening the cow cattleto be ready to sold and the income of the breeder. Because according to [1] and [18] feed ingredient overflowing in the village and it does not fully take the optimized benefit of it yet such as lamtoro leaf, turi, rice-plant straw, corn straw and nut seal.

\section{MATERIAL AND METHOD}

This research used ingredient feed such as brown sugar, coconut water, lamtoro and gamal, rice-plant straw, bran, banana tree stem, tofu waste, salt, urea, corn leaf, and molasses. These ingredients were made as fermented or complete feed to fattening cow breeder in September 2017

Research approach in this fermented feed making is done with learning by doing. But preceded with by fill the questionnaire that has been ready with the purpose to measure the knowledge of 25 cow breeders as analysis unit or it is called free test, and then practiced to make fermented feed or complete by 25 cow breeders that get accompaniment from Animal Husbandry Faculty Hasanuddin University trainers in Gowa Regency,South Sulawesi Province. After fermented feed is ready it directly tested with 5 cows own by cow breeder. This case aiming to convince breeder about fermented feed or complete that already been made.

After the practice is done the 25 breeders gathering into the room to do a post test through fill in the questionnaire which has been prepared. This is intended to measure the knowledge of breeder before and after the fermented feed making implementation or commonly known as a free test and post-test group design. [19, 20] said that to do evaluation knowledge measuring respondent so that it can be done with free test and post-test group design.

\section{RESULT AND DISCUSSION}

The result of research show that 25 cow cattle breeders that giving the training to make fermented feed or complete feed with learning by doing method showing that before the training has been done there are 20 breeders did not know yet the benefit agricultural waste around the area where they live that it can be made as 
fermented feed, and there are 5 cow cattle breeders already get the information about fermented feed but do not know how to make it.

After the training is done with learning by doing with coaching and accompaniment in making of fermented feed and it tested to 5 cattle cows the result show 25 cow breeder know and satisfied with that fermented technology. For more clearly result of the research shows on Table 1.

Table 1: Cow Breeder knowledge Before and After getting Research Fermented Feed Making

\begin{tabular}{|l|l|l|l|l|}
\hline \multirow{2}{*}{ No. } & \multirow{2}{*}{ Feed Type } & Breeder Knowledge & \multirow{2}{*}{$\begin{array}{l}\text { Progress } \% \\
\text { nnyynn} \\
\text { (people) }\end{array}$} \\
\hline 1. & Forage & 25 & 25 & 0,00 \\
\hline 2. & Fermented/Complete & 0 & 25 & 100,00 \\
\hline
\end{tabular}

Source: Process of Primary Data, 2016

Table 1 . Showed that 25 cow cattle breeder whose already utilize forage that they really mastered because it already have been habit to give forage to their cattle to fattening them in 4 months meanwhile with fermented feed making treatment or complete feed and the benefit at the start there are 25 breeders that do not know how to make, and after the training is done there are 25 breeders $(100 \%)$ know how to do it and the benefit of fermented feed is for fattening cow cattle in 4 months. It is mean that the breeder knowledge have been increasing from using field forage or shepherded to become fermented feed or complete which have the right nutrition content to fattening the cow cattle. [21] support this research result with the fermented feed that given to the Bali cow can increase the daily weight gain 700 gram/day/cow. Also [17] support this research result because with fermented feed that given to Bali cow can increase the daily weight gain per cow 200 gram/day.

Accordance with the research result there are 25 cow cattle breeders that apply fermented feed that has been given to them showed the daily weight gain per cow 200 gram/day.

Table 2: Comparison of Daily Weight gain per cow Bali cow cattle using shepherded forage and fermented for 4 months.

\begin{tabular}{|l|l|l|l|l|}
\hline No. & Feed Type & $\begin{array}{l}\text { Number of breeders } \\
(\text { people })\end{array}$ & $\begin{array}{l}\text { Average Daily weight gain } \\
\text { per cow }(\mathrm{kg})\end{array}$ & $\begin{array}{l}\text { Duration of Feeding } \\
(\mathrm{month})\end{array}$ \\
\hline 1. & Forage / Shepherded & 25 & 0,15 & 4 \\
\hline 2. & Fermented / Complete & 25 & 0,35 & 4 \\
\hline
\end{tabular}

Source: Process of Primary Data, 2016

From table 2 showed that fermented feed more benefit if u see from daily weight gain per cow that reach for 4 months if comparing to the used of field forage that each of its $0,35 / \mathrm{kg} / \mathrm{cow} /$ day and $0,15 / \mathrm{cow} /$ day. It is mean if Bali cow is given fermented feed so that the fattening Bali cow can be marketing fast and the optimal weight can reach according to market needs.

According to the daily weight gain per cow Bali cow that has been fattening for 4 months so that the comparison for the profit that obtained from using forage field and fermented feed after being analyzed with financial economically so the breeder that using fermented feed more benefit compare to the forage field. To make it clear can be seen in table 3.

Table 3: Financial Economy Analysis Bali Cow cattle fattening with Using Forage field and fermented feed for 4 months

\begin{tabular}{|l|l|l|l|l|l|l|}
\hline No. & Feed Type & $\begin{array}{l}\text { PBBH } \\
\text { Kg/day/cow }\end{array}$ & $\begin{array}{l}\text { Duration of } \\
\text { fattening } \\
\text { (month) }\end{array}$ & $\begin{array}{l}\text { Sale Price } \\
\text { Per kilogram } \\
\text { (IDR) }\end{array}$ & $\begin{array}{l}\text { Expense } \\
\text { (IDR) }\end{array}$ & $\begin{array}{l}\text { The Breeder profit } \\
\text { per cow (IDR) }\end{array}$ \\
\hline 1. & Field Forage & 0,15 & $4(120)$ & 80.000 & - & $1.440 .000,00$ \\
\hline 2. & Fermented & 0,35 & $4(120)$ & 80.000 & 270.000 & $3.090 .000,00$ \\
\hline
\end{tabular}

Source: Process of Primary Data, 2016

From table 3 it can be seen that the profit that can be earn per cow by the cow cattle breeder with the using of fermented feed IDR. 3.090.000,00 and field forage IDR. 1.440.000,00, so that the difference of profit that can be earned by the breeder is IDR $1.650 .000,00$. It is mean with the profit that can be earned by the breeder from fattening Bali cow can impact with the supply cow cattle from the breeder to the market can always be fulfill so that the continuity of supply chain can be maintained.

\section{Conclusion:}

Technology adoption fermented feed or complete feed that given as learning by doing to the breeder gives the attitude change to the cow cattle breeder knowledge from using field from as shepherded to used fermented feed or complete feed because it gives more benefit for the daily weight gain and the duration of cow cattle fattening is really in just in a short time and also it give profit financially. 


\section{REFERENCES}

[1] Dixon, R.M. and A.R. Egan, 1987. Strategies for Optimizing Use of Fibrous Agriculture Residues.IDP. Canberra.

[2] Sirajuddin S, Asnawi N, Rasyid A, Mangalizu I, Masnur A. 2016. Competitiveness of Beef Cattle Fattening in Kulo Subdistrict, Sidrap District South Sulawesi. Advances in Environmental Biology. 10(1):171-5.

[3] Central Bureau of Statistics, 2006. Statistics Indonesia, BPS. Jakarta

[4] Sirajuddin, S.N., S. Hastang, A. Rohani, Salam. 2015. Competitiveness level Fattening Beef Cattle in Polewali Mandar, West Sulawesi Province. Advances in Environmental Biology, 9(23): 322-325

[5] Stiir, W.W., and P.M. Horne, 2001. Developing Forage Forage Joint Technology Small Farmers. Cooperation ACIAR and The Director General of Livestock and Animal Husbandry Department of East Kalimantan.

[6] Hasan, S., 2012. Empowerment Dryland and Critical Via Integration Forage and Ruminant Feed.

[7] Ramos, A.V., M. Torre de La and C.L. Campilo, 1983. Solid State Fermentation of Cassava with Rhizopus Oligosporus NRRL 2710 In: Production and Feeding of Single Cell Protein. Eds. Ferranti M.P. and Fletcher A. Apllier Science Publisher. London.

[8] Sirajuddin, S. N., Asnawi, A., Syawal, S., \& Jamal, M. 2016. Response of cattle breeders to rice straw silage in Soppeng Regency, South Sulawesi Province. American-Eurasian Journal of Sustainable Agriculture, 10(3), 33-37.

[9] Tanrigiling Rasyid., Syamsuddin Hasan., Syamsuddin Rasyid., St. Nurani Sirajuddin, 2016. Dissertation. Development Modal of Goat Farming Bussiness Base on Productive Economy in Majene Regency.West Sulawesi. Indonesia. Hasanuddin University

[10] Sirajuddin, S. N., ramadhan Siregar, A., \& Mappigau, P. (2017). Adoption Rate of Beef Breeders Technology Following Partnership System in Barru Regency. American-Eurasian Journal of Sustainable Agriculture, 11(6), 31-34.

[11]Wahyono, E., 2015. Full Feed Technology as Solution agi Ruminant Feed Problems. UPTD.Jatinegoro.West Java.

[12] Van Soest, 1982. Consumption and Nutrient Digestibility Coefficient on Etawa Given Goat Ranch Feed Concentrate. Udayana Faculty of Animal Science. Denpasar Bali. Indonesia.

[13] Simanuhuruh, 2006. Utilization of Forage Legume as Growth Phase Goats. Goat Research Station.North Sumatra.

[14] Okine, 2007. Carrying Feed Enhancement Technology in Region Horticulture for Goat. Goat Research Station.North Sumatra.

[15] Ginting, S.P., 2007. Benefits of Industrial Waste Processing Vegetable Radish.Proceedings of Animal Husbandry and Veterinary Technology. Puslitbangnak. Bogor. Indonesia.

[16] Veronica Sri Lestari., Djoni Prawira Rahardjo., Tanrigiling Rasyid, 2016. Beef Cattle Farmers Perception Toward Urea Mineral Molasses Block. International Journal of Biological, Biomolecular, Agriculture, Food and Biotechnological Engineering, Waste.org/publication/1005758.

[17] Marsetyo, 2008. Strategic Fulfillment Feed for Increased Productivity and Population Cattle. Proceedings of the National Seminar on Beef Cattle. Faculty of Animal Husbandry Tadulako. Palu. Central Sulawesi.

[18] Amiruddin, S., 1997. Some type and Preservation Methods Tropical Foliage Feed. Faculty of Animal Husbandry. University General Sudirman. Purwokerto. Indonesia.

[19] Arikunto Suharsini, 2002. Research Produce A Practice Approach. Rineka Reserved. Jakarta. Indonesia.

[20] Sirajuddin, S. N., \& Kurniawan, M. E. (2016). Level technology adoption and characteristic cattle breeders who following Bachelor Village Building. American-Eurasian Journal of Sustainable Agriculture, 10(5), 28-33..

[21] Siregar, A.R. and C. Talib, 1992. Cattle Bali and Ongole in Tawaeli, Central Sumatra.Proceeding Ranch Rural Agroindustry. Livestock Research Institute. Bogor.

[22] Sirajuddin, S. N., Malaka, R., \& Kasirang, A. 2017. Factors cause reduction of members of fresh milk production cooperative dairy cattle breeder. American-Eurasian Journal of Sustainable Agriculture, 11(2), $1-7$.

[23] Sirajuddin, S. N., Siregar, A. R., Nurlaelah, S., Lestari, V. S., \& Tenrisanna, V. 2017. The limitations and benefits of partnership sharing system of Corporated Cattle Market (CCM). American-Eurasian Journal of Sustainable Agriculture, 11(1), 11-15.

[24] Sirajuddin, S. N., Ramadhan Siregar, A., \& Mappigau, P. 2017. Adoption Rate of Beef Breeders Technology Following Partnership System in Barru Regency. American-Eurasian Journal Of Sustainable Agriculture, 11(6), 31-34. 